\title{
Keratin 5 overexpression is associated with serous ovarian cancer recurrence and chemotherapy resistance
}

\author{
Carmela Ricciardelli ${ }^{1}$, Noor A. Lokman ${ }^{1}$, Carmen E. Pyragius $^{1}$, Miranda P. Ween ${ }^{2}$, \\ Anne M. Macpherson ${ }^{1}$, Andrew Ruszkiewicz ${ }^{3}$, Peter Hoffmann ${ }^{4}$, Martin K. Oehler ${ }^{1,5}$ \\ ${ }^{1}$ Discipline of Obstetrics and Gynaecology, School of Medicine, Robinson Research Institute, University of Adelaide, Adelaide, \\ 5000, South Australia, Australia \\ ${ }^{2}$ Lung Research Laboratory, Hanson Institute, Adelaide, South Australia, Australia, Department of Thoracic Medicine, Royal \\ Adelaide Hospital, Adelaide, 5000, South Australia, Australia \\ ${ }^{3}$ Centre of Cancer Biology, University of South Australia and Department of Anatomical Pathology, SA Pathology, Adelaide, \\ 5000, South Australia, Australia \\ ${ }^{4}$ Adelaide Proteomics Centre, School of Biological Sciences, University of Adelaide, Adelaide, 5005, South Australia, Australia \\ ${ }^{5}$ Department of Gynaecological Oncology, Royal Adelaide Hospital, Adelaide, 5000, South Australia, Australia \\ Correspondence to: Carmela Ricciardelli, email: carmela.ricciardelli@adelaide.edu.au \\ Keywords: ovarian cancer, keratin 5, tumor progression, recurrence, chemoresistance \\ Received: October 01, 2015 \\ Accepted: January 16, 2017 \\ Published: January 27, 2017
}

\section{ABSTRACT}

This study investigated the clinical significance of keratin 5 and 6 expression in serous ovarian cancer progression and chemotherapy resistance. KRT5 and KRT6 (KRT6A, KRT6B \& KRT6C) gene expression was assessed in publically available serous ovarian cancer data sets, ovarian cancer cell lines and primary serous ovarian cancer cells. Monoclonal antibodies which detect both K5/6 or only K5 were used to assess protein expression in ovarian cancer cell lines and a cohort of high grade serous ovarian carcinomas at surgery $(n=117)$ and after neoadjuvant chemotherapy $(n=21)$. Survival analyses showed that high KRT5 mRNA in stage III/IV serous ovarian cancers was significantly associated with reduced progression-free (HR 1.38, $P<0.0001$ ) and overall survival (HR 1.28, $P=0.013$ ) whilst high KRT6 mRNA was only associated with reduced progression-free survival (HR 1.2, $P=0.031$ ). Both high K5/6 ( $\geq 10 \%$, HR 1.78 95\% CI; 1.03-2.65, $P=0.017)$ and high K5 ( $\geq 10 \%$, HR 1.90, $95 \% \mathrm{CI} ; 1.12-3.19, P=0.017)$ were associated with an increased risk of disease recurrence. KRT5 but not KRT6C mRNA expression was increased in chemotherapy resistant primary serous ovarian cancer cells compared to chemotherapy sensitive cells. The proportion of serous ovarian carcinomas with high $\mathrm{K5} / 6$ or high $\mathrm{K5}$ immunostaining was significantly increased following neoadjuvant chemotherapy. K5 can be used to predict serous ovarian cancer prognosis and identify cancer cells that are resistant to chemotherapy. Developing strategies to target $\mathrm{K5}$ may therefore improve serous ovarian cancer survival.

\section{INTRODUCTION}

Ovarian cancer is the most lethal gynaecological cancer and the sixth most common cause of cancer related death among Western women [1]. Although ovarian cancers represent only $30 \%$ of cancers of the female genital tract, they are responsible for half of the deaths [1]. The disproportionately high mortality rate is attributed to the late presentation of the disease. Despite advances in surgery and chemotherapies, no substantial improvement in ovarian cancer survival has been observed over the last two decades [2]. A greater understanding of the mechanisms involved in the progression of ovarian cancer will aid in the discovery of novel molecular prognostic indicators as well as new therapeutic targets. To increase our understanding of the molecular mechanisms involved in ovarian cancer progression and to identify novel therapeutic targets we recently studied the interaction of ovarian cancer and peritoneal cells [3-5]. Keratins K5 and $\mathrm{K} 6 \mathrm{c}$ were amongst the proteins that were identified in the ovarian cancer peritoneal cell co-culture secretome by MALDI-TOF/TOF mass spectrometry [5]. 
Keratins are intermediate filament proteins responsible for structural integrity of epithelial cells and play an important role in epithelial cell protection. They also play roles in cell polarization, cell size regulation, protein translation and organelle positioning [6]. Fifty four functional keratin proteins have been identified in human epithelial cells including 28 type I (acidic forms, K9-K28) and 26 type II (basic forms, K1-K8 and K71-K74) proteins $[7,8]$. They contain a central rod of $\sim 310$ amino acids with a helical conformation flanked by non-helical head and tail domains of variable length [9]. A characteristic feature of keratin proteins is their pairing with other keratin proteins. They form obligate heterodimers between a type I keratin and a type II keratin via their rod domains and the resulting heterodimers and tetramers form the basic building units of the keratin filaments [7, 8].

K5 (encoded by gene KRT5) is a high molecular weight (predicted $62.6 \mathrm{kDa}$ ), basic type keratin expressed in the basal, intermediate, and superficial layers of stratified epithelia as well as transitional epithelia and complex epithelium [9]. It is most often complexed with K14 [9]. K5 positive cells have been identified in both luminal and basal epithelium of the normal breast and K5 has been implicated as a stem cell marker [10, 11]. A recent study has highlighted that $\mathrm{K} 5$ expressing basal cells in the healthy and regenerating urothelium are self-renewing and unipotent [12].

K6 protein is also a high molecular weight (predicted $60.3 \mathrm{kDa}$ ), basic type keratin known to be expressed by proliferating squamous epithelia and usually complexes with K16 [9]. Three isoforms of K6 exist (K6a, K6b, and K6c) which are encoded by three distinct genes: KRT6A, KRT6B, and KRT6C [13, 14]. K6a is the most abundant, representing about $77 \%$ of all forms found in epithelia and shares at least $97.6 \%$ amino acid identity with other K6 proteins. K6a has been detected in subpopulations of luminal and ductal myoepithelial cells in human mammary glands [15]. A high proliferative population of K6a positive cells has also been described in the prostate gland [16]. There have been only a few studies which have investigated the expression of the K6c isoform in human tissues as until recently there was a lack of isoform-specific gene probes and antibodies.

Monoclonal antibodies to $\mathrm{K} 5$ and $\mathrm{K} 5 / 6$ have been used to identify basal-like triple negative breast cancers $[17,18]$ and high $\mathrm{K} 5 / 6$ expression was found to be associated with an increased risk of breast cancer relapse and death $[17,19,20]$. Focal K5/6 expression has also been described in adenocarcinomas of the endometrium, pancreas and ovary [21, 22]. In addition, $\mathrm{K}^{+}$subpopulation of cells have been identified in $\mathrm{ER}^{+}$ $\mathrm{PR}^{+}$luminal breast cancers $[23,24]$ and are increased in patients whose luminal breast cancers develop resistance to endocrine treatment and chemotherapy $[25,26]$.

Whilst other keratins have been shown to have diagnostic or prognostic utility in ovarian cancer [27-30], limited studies to date have examined $\mathrm{K} 5$ and $\mathrm{K} 6$ expression in this malignancy. We therefore investigated the prognostic significance of KRT5 and KRT6 mRNA expression in publically available serous ovarian cancer data sets [31]. Additionally, monoclonal antibodies which detect both $\mathrm{K} 5 / 6$ or only K 5 were used to assess protein expression in ovarian cancer cell lines and cohorts of high grade serous ovarian carcinomas at surgery and after neoadjuvant chemotherapy. Furthermore, KRT5 and KRT6C mRNA expression was assessed in chemotherapy sensitive and chemotherapy resistant primary serous ovarian cancer cells derived from patient ascites. We also evaluated whether $\mathrm{K}^{+}$cells are increased in serous ovarian cancer patients following chemotherapy treatment. To our knowledge, this is the first study to investigate the relationships between KRT5 mRNA, KRT6 mRNA, K5/6, and $\mathrm{K} 5$ protein expression with serous ovarian cancer patient outcome.

\section{RESULTS}

\section{KRT5, KRT6C mRNA and K5/6 protein expression in ovarian cancer cell lines}

Using qRT-PCR KRT5 is expressed by metastatic OVCAR-5, OV-90, and SKOV-3 ovarian cancer cells, as well as by poorly metastatic OVCAR-3 cells but not the peritoneal cell line, LP-9 (Figure 1A). KRT6C was expressed by all ovarian cancer cell lines as well as LP-9 cells (Figure 1B). The K5/6 antibody detected bands at $\sim 52 \mathrm{kDa}$ in all cell line extracts and faint bands at $\sim 56 \mathrm{kDa}$ in protein extracts from OVCAR-5, OV-90 and SKOV-3 cells (Figure 1C). Using human ovarian cancer tissue extracts shown to express high and low K5/6 and K5 positivity (see inserts in Figure 1C and 1D) and antibodies to only $\mathrm{K} 5$, we confirmed that the $56 \mathrm{kDa}$ and $52 \mathrm{kDa}$ bands were $\mathrm{K} 5$ and $\mathrm{K} 6$, respectively. Two bands at $\sim 52$ $\mathrm{kDa}$ and $\sim 56 \mathrm{kDa}$ were observed with the $\mathrm{K} 5 / 6$ antibody in the ovarian cancer tissue extracts (Figure 1C), however the $\mathrm{K} 5$ antibody (Abcam) only detected a single band at $\sim 56 \mathrm{kDa}$ in the ovarian cancer tissue (Figure 1D).

\section{$\mathrm{K5} / 6$ and $\mathrm{K} 5$ are elevated in serous carcinoma tissues}

$\mathrm{K} 5 / 6$ immunostaining was abundant in the skin epidermis (Figure 2A) but little or no staining was observed in the ovarian surface epithelium (OSE) of normal ovaries (8/8, Figure 2B, Table 1A). High K5/6 immunostaining (score 2 or 3 ) was present in $25 \%(2 / 8)$ of the benign serous cystadenoma (Figure 2C, Table 1A), 60\% (6/10) high grade serous borderline tumors (Figure 2D, Table 1A) and $29.9 \%(35 / 117)$ of the serous ovarian cancer cases (Table 1A). Sixteen percent (19/117) of the serous ovarian cancer tissues were negative for K5/6. Examples of low $($ score $=1)$ and high $($ score $=3)$ K5/6 immunostaining 
in serous ovarian cancer tissues are shown in Figure $2 \mathrm{E}$ and $2 \mathrm{~F}$, respectively. $\mathrm{K} 5 / 6$ immunostaining was increased in serous borderline tumors and serous carcinomas compared to normal ovaries $(P=0.006$, Chi-Square test, Table 1A). Similar staining patterns were observed with a monoclonal antibody which detects only K5 (Table 1C), (Supplementary Figure 1). However, a higher proportion of serous carcinomas $(66 \%, 70 / 106)$ had high K5 immunostaining compared to K5/6 immunostaining. Neither K5/6 nor K5 immunostaining were associated with patient age, FIGO stage, tumor grade or the presence of residual disease (Supplementary Table 1).

\section{Relationship of KRT5 and KRT6 mRNA and $K 5 / 6$ protein expression with patient outcome}

Using the publically available Kaplan-Meir online plotter tool which incorporates gene expression data from 13 ovarian cancer sets including the TCGA dataset [31], high KRT5 expression was associated with reduced

A

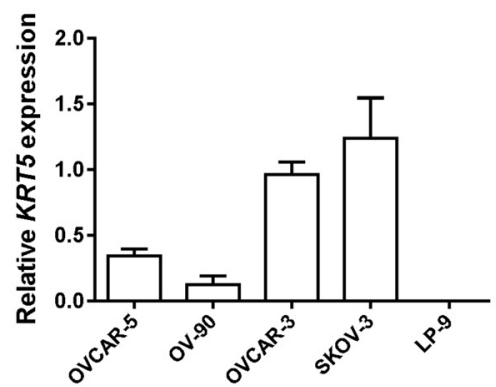

C

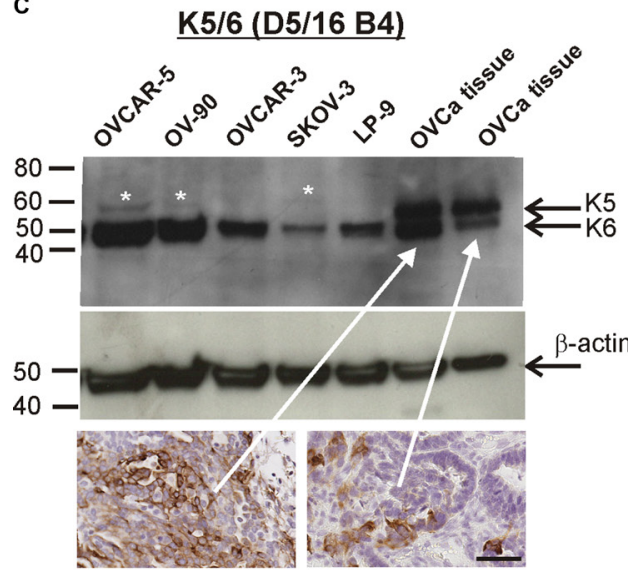

progression-free survival (PFS, HR 1.38; 95\% CI 1.16-1.64, $P<0.0001$, Figure 3A) and overall survival (OS, HR 1.28 95\%; CI 1.05-1.56, $P=0.013$, Figure 3B). High KRT6 expression was also associated with reduced PFS (HR $1.26 ; 95 \%$ CI 1.07-1.47, $P=0.005$, Figure 3C) but not OS (Figure 3D). No statistical correlation was found between KRT5 or KRT6 expression with patient age at diagnosis, tumor stage, tumor grade, or size of residual tumor after cytoreductive surgery in the TCGA dataset (data not shown).

We confirmed in a cohort of advanced stage serous ovarian cancers that patients with high K5/6 or high K5 immunostaining ( $\geq 10.0 \%$ ) had a significantly reduced PFS compared to patients with low K5/6 or low K5 positivity ( $<10.0 \%$, Figure 4A, 4C). The 24 months PFS rate was $34.4 \%$ in the group of patients with $\mathrm{K} 5 / 6$ positivity $<10 \%$ and only $10.5 \%$ in the group of patients with $\mathrm{K} 5 / 6$ positivity $\geq 10 \%$. The 24 months PFS rate was $48.5 \%$ in the group of patients with $\mathrm{K} 5$ positivity $<10 \%$ and only $27.7 \%$ in the group of patients with $\mathrm{K} 5$ positivity $\geq 10 \%$. Neither K5/6 nor K5 immunostaining
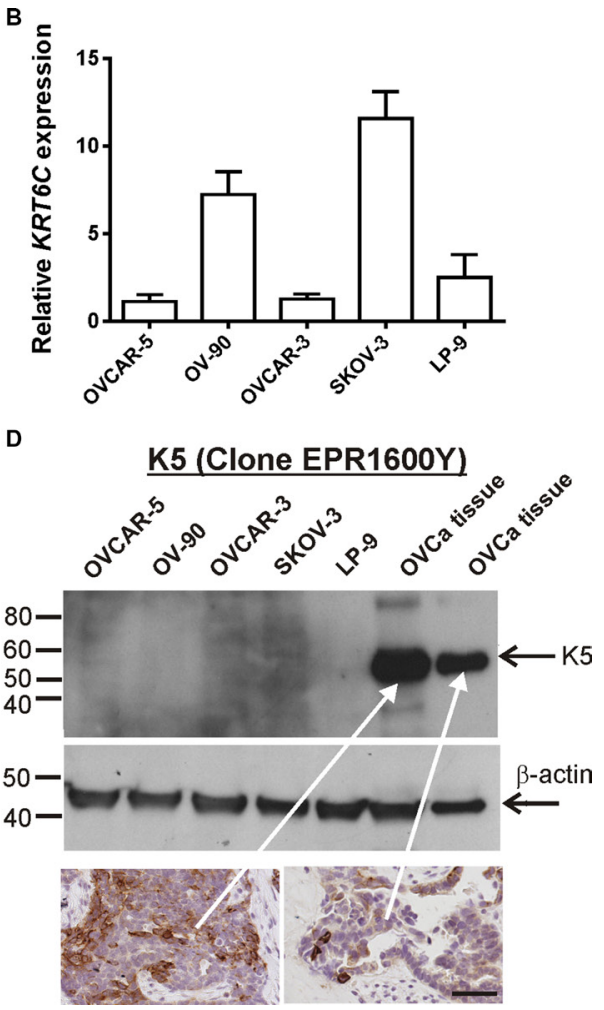

Figure 1: KRT5, KRT6C mRNA, K5/6 and K5 expression in ovarian cancer cell lines. (A) KRT5 mRNA expression in ovarian cancer cell lines and LP-9 cells. (B) KRT6C mRNA expression in ovarian cancer cell lines and LP-9 cells. Relative expression was normalized to the house keeping gene $\beta$-actin using the $2^{-\Delta \Lambda C T}$ method with the same calibrator (OVCAR-3). Data is expressed as the mean fold change \pm SEM from 4-11 individual RNA samples obtained from 2-4 independent experiments. (C) Equal amounts protein for the cell lines $(40 \mu \mathrm{g})$ and ovarian cancer tissue extracts $(5 \mu \mathrm{g})$ were run on a 4-20\% SDS-PAGE gel and immunoblotted with mouse monoclonal K5/6 antibody (1/200, clone D5/16 B4, Dako). K5/6 antibody detected K6 bands at $\sim 52 \mathrm{kDa}$ in all cell line extracts and faint K5 bands at $\sim 56 \mathrm{kDa}$ in cell extracts from OVCAR-5, OV-90 and SKOV-3 cells. Both K5 and K6 were detected in ovarian cancer tissue extracts. White asterisks indicate faint K5 bands detected with K5/6 antibody. (D) Western blotting with rabbit monoclonal K5 antibody (1/5000, clone EPR1600Y, Abcam) antibody using the same protein samples from (C) confirmed K5 expression in ovarian cancer tissue extracts. A mouse monoclonal antibody to $\beta$-actin (1/10,000, clone AC-15, Sigma Aldrich A3854) was used as a loading control. Ovarian cancer tissues sections with high and low K5/6 (C) or K5 (D) immunostaining were used as positive controls for the western blots (scale bar $=50 \mu \mathrm{m})$. 
was associated with OS (Figure 4B, 4D). Cox regression analysis also indicated that patients with high $\mathrm{K} 5 / 6$ positivity $(\geq 10 \%)$ had a 1.78 fold increased risk of disease relapse (95\% CI; 1.01-2.66, $P=0.017$, Table 2). High K5 positivity was associated with a 1.90 fold increased risk of disease relapse $(95 \% \mathrm{CI} ; 1.12-3.19, P=0.017$, Table 2$)$. Other clinical and pathological parameters including patient age, clinical stage, tumor grade, and the presence of residual disease were not associated with PFS or OS in this advanced stage serous ovarian cancer cohort (Table 2).

\section{KRT5 mRNA and K5 protein levels are elevated following chemotherapy treatment}

K5/6 was increased in serous ovarian cancer tissues following chemotherapy compared with chemonaïve tissues $(P<0.0001$, Table 1B). Increased $\mathrm{K} 5 / 6$ immunostaining is evident in the images in Figure $2 \mathrm{G}$ and $2 \mathrm{H}$ that are an example of matching tissues from the same patient before and after chemotherapy treatment, respectively. Similar results were observed with the K5 monoclonal antibody (Table 1C, Supplementary Figure $1 \mathrm{G}$ and $1 \mathrm{H})$. These findings are supported by mRNA expression studies in chemosensitive and chemoresistant primary ovarian cancer cells. KRT5 but not KRT6C mRNA expression was increased in primary cells derived from patients' ascites with recurrent chemoresistant disease $(n=10)$ compared with primary cells from patients who responded to the chemotherapy treatment ( $n=9$; Figure 5A and 5B, $P=0.0006$, Mann Whitney $\mathrm{U}$ test). KRT5 (Figure 5A), KRT6C mRNA (Figure 5B) and $\mathrm{K} 5$ protein (Figure $5 \mathrm{C}$ and $5 \mathrm{D}$ ) were increased in OVCAR-5 cells made resistant to carboplatin (OVCAR5-CBPR) compared with the parental OVCAR-5 cells by immunofluoresence. Furthermore, treatment with an $\mathrm{IC}_{50}$ dose of carboplatin significantly increased the number of
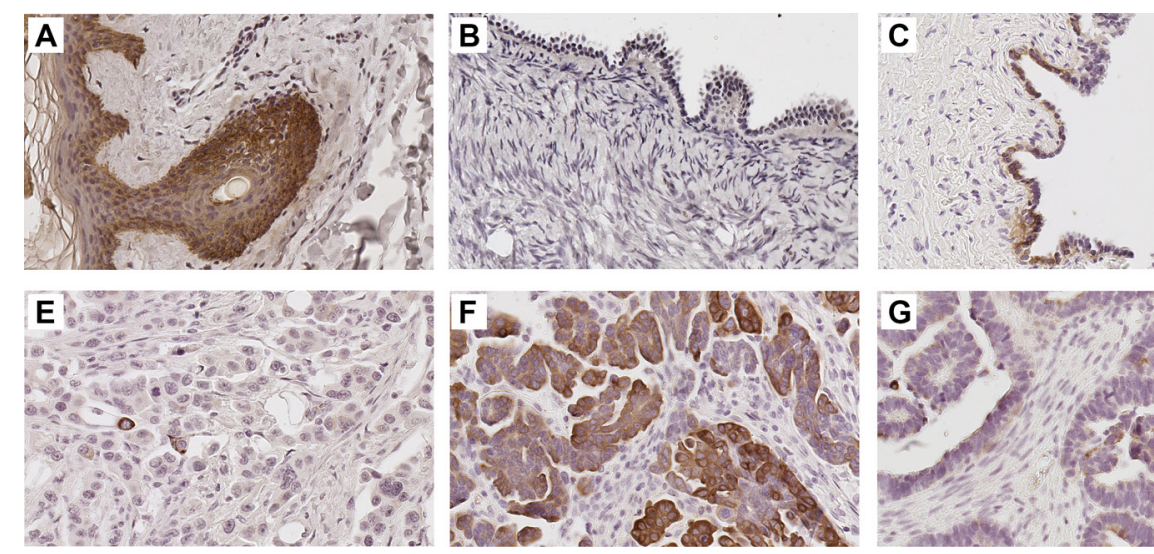

$\mathrm{K}^{+}$cells in 4 serous ovarian cancer cell lines (OVCAR-5, OVCAR-3, OAW28 and COV362) (Figure 5C and 5D).

\section{DISCUSSION}

High grade serous ovarian carcinomas account for nearly $70 \%$ of ovarian malignancies. They are characterized by high initial chemosensitivity to platinum based therapies, however $75 \%$ of patients relapse after treatment and subsequently become chemotherapy resistant [32]. The development of more effective molecularly targeted therapies to improve survival is urgently required. In this study we show that 1) KRT5 and $K R T 6 C$ are expressed by ovarian cancer cell lines, 2) $K R T 5$ expression levels predict reduced PFS and OS for serous ovarian cancer patients, 3) KRT6 expression levels predict reduced PFS but not OS for serous ovarian cancer patients, 4) Both high K5/6 or high K5 positivity in serous ovarian cancers can predict reduced PFS but not OS, 5) $\mathrm{K} 5 / 6$ and $\mathrm{K} 5$ immunostaining is increased in serous ovarian cancers following neoadjuvant chemotherapy, 6) KRT5 expression levels but not KRT6C are increased in serous primary cells derived from patients' ascites with chemoresistant disease and 7) K5 protein expression is increased in serous ovarian cancer cell lines following carboplatin treatment. Our findings indicate that K5 expression could be used to predict serous ovarian cancer prognosis and may be used to identify cancer cells that are resistant to chemotherapy.

$\mathrm{K} 5$ is usually detected using a K5/6 combination monoclonal antibody (clones D5/16B4) as it is closely related to $\mathrm{K} 6$. Co-expression of $\mathrm{K} 5$ and $\mathrm{K} 6$ has been reported in a number of different types of neoplasms including basal cell carcinoma [33], prostate cancer $[34,35]$, ductal breast carcinoma [36-38], mesothelioma [39, 40], lung carcinomas [41], melanoma, basal cell
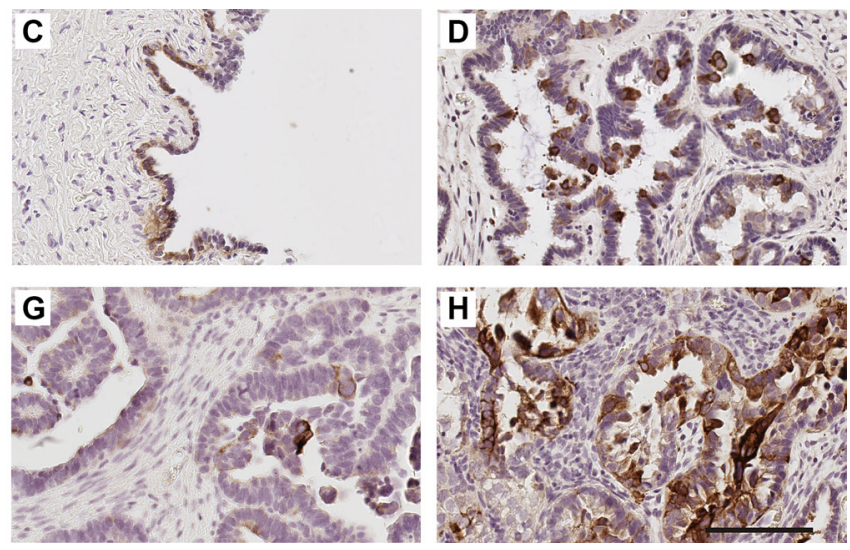

Figure 2: K5/6 expression in human ovarian tissues. K5/6 immunohistochemistry using mouse monoclonal K5/6 antibody (1/50, clone D5/16 B4, DAKO) using Tris buffer ( $\mathrm{pH} 9.0$ ) microwave antigen retrieval. Human skin (A), normal ovary (B), benign serous cystadenoma (C), serous borderline tumor (D), serous carcinoma with low K5/6 immunostaining (E) serous carcinoma with high K5/6 immunostaining (F). K5/6 immunostaining in tissues obtained from the same patient at diagnosis (G) and following treatment carboplatin and paclitaxel $\mathbf{( H )}$. Scale bar $=100 \mu \mathrm{m}$. All images are same magnification. 
Table 1: Comparison of K5/6 and $\mathrm{K5}$ immunostaining in different tissues groups

A. K5/6 immunostaining in normal ovaries, benign serous cystadenomas, serous borderline tumors and serous ovarian carcinomas

\begin{tabular}{|l|c|c|c|c|}
\hline \multirow{2}{*}{ Tissue } & \multicolumn{4}{c}{ K5/6 immunostaining (positivity groups) } \\
\cline { 2 - 5 } \multicolumn{1}{c}{} & $\mathbf{0}$ & $\mathbf{1}(\mathbf{1 - 9 \% )}$ & $\mathbf{2}(\mathbf{1 0 - 5 0 \% )}$ & $\mathbf{3}(\mathbf{5 0 \% )}$ \\
\hline \multirow{2}{*}{ Normal ovaries } & $5 / 8$ & $3 / 8$ & $0 / 8$ & $0 / 8$ \\
& $(62.5 \%)$ & $(87.5 \%)$ & $(0 \%)$ & $(0 \%)$ \\
\hline \multirow{2}{*}{ Serous cystadenomas } & $0 / 8$ & $6 / 8$ & $2 / 8$ & $0 / 8$ \\
& $(0 \%)$ & $(75 \%)$ & $(25 \%)$ & $(0 \%)$ \\
\hline \multirow{2}{*}{ Serous borderline tumors } & $0 / 10$ & $4 / 10$ & $3 / 10$ & $3 / 10$ \\
& $(0 \%)$ & $(40 \%)$ & $(30 \%)$ & $(30 \%)$ \\
\hline \multirow{2}{*}{ Serous ovarian carcinomas (Stage III-IV) } & $19 / 117$ & $64 / 117$ & $24 / 117$ & $10 / 117$ \\
& $(16.2 \%)$ & $(54.7 \%)$ & $(20.5 \%)$ & $(8.5 \%)$ \\
\hline Chi-squared test & \multicolumn{3}{|c|}{$P=0.006$} & \\
\hline
\end{tabular}

B. K5/6 immunostaining in chemonaive serous ovarian cancers and post chemotherapy treatment

\begin{tabular}{|c|c|c|c|}
\hline \multirow{2}{*}{ Tissue } & \multirow{2}{*}{$n$} & \multicolumn{2}{|c|}{ K5/6 immunostaining (positivity groups) } \\
\hline & & $<10 \%$ & $\geq 10 \%$ \\
\hline Serous ovarian carcinomas (chemonaïve) & 117 & $\begin{array}{c}82 / 117 \\
(70.1 \%)\end{array}$ & $\begin{array}{c}35 / 117 \\
(29.9 \%)\end{array}$ \\
\hline Serous ovarian carcinoma (Post chemotherapy & 21 & $\begin{array}{c}3 / 21 \\
(14.3 \%)\end{array}$ & $\begin{array}{c}18 / 21 \\
(85.7 \%)\end{array}$ \\
\hline Fisher exact test & & \multicolumn{2}{|c|}{$P<0.0001$} \\
\hline
\end{tabular}

C. K5 immunostaining in chemonaive serous ovarian cancers and post chemotherapy treatment

\begin{tabular}{|c|c|c|c|}
\hline \multirow{2}{*}{ Tissue } & \multirow{2}{*}{$n$} & \multicolumn{2}{|c|}{ K5 immunostaining (positivity groups) } \\
\hline & & $<10 \%$ & $\geq 10 \%$ \\
\hline Serous ovarian carcinomas (chemonaïve) & 106 & $\begin{array}{c}36 / 106 \\
(34.0 \%)\end{array}$ & $\begin{array}{c}70 / 106 \\
(66.0 \%)\end{array}$ \\
\hline Serous ovarian carcinoma (Post chemotherapy & 21 & $\begin{array}{c}1 / 21 \\
(4.8 \%)\end{array}$ & $\begin{array}{c}20 / 21 \\
(95.2 \%)\end{array}$ \\
\hline Fisher exact test & & \multicolumn{2}{|c|}{$P=0.007$} \\
\hline
\end{tabular}

carcinoma, and salivary gland tumors [22]. K5/6 overexpression is associated with poor prognosis of basallike breast cancers $[17,18,42]$ and was found to be an independent indicator of recurrence-free survival and/or OS in breast cancer $[17,19,20,43]$. The K5/6 monoclonal antibody has been used for the diagnosis of poorly differentiated squamous carcinomas and undifferentiated nasopharyngeal carcinomas $[21,22]$. It can distinguish between small cell lung carcinomas which are $\mathrm{K} 5$ negative and malignant mesothelioma which are K5 positive $[21,22]$. K5/6 has superior sensitivity and reliability in differentiating between benign and malignant prostate glands when compared with K903 (high molecular weight keratins); and [34] it has been used successfully in a five antibody panel (which also targets TRIM29, CEACAM5, SLC7A5, MUC1) to better classify the subtypes of lung carcinoma [44]. The expression of K5/6 together with p63 has also been used to differentiate between adenosquamous carcinomas and adenocarcinomas in pleural effusion samples $[45,46]$. Recently, K5 positive basal cells have also been identified as progenitors of bladder cancers [47].

Several studies have investigated the expression of $\mathrm{K} 5 / 6$ in ovarian cancer but to date $\mathrm{K} 5$ or K6 expression has not been linked with ovarian cancer outcome. The incidence of $\mathrm{K} 5 / 6$ positivity ( $29.9 \%$, Table $1 \mathrm{~B}$ ) in our study was similar to that observed in previous ovarian cancer studies which ranged from $25 \%$ to $55.4 \%$ [22, 48, 49]. However we observed a higher proportion of serous carcinomas (66\%, Table 1C) with high K5 immunostaining which is comparable to a recent study reporting 50\% K5 positivity in serous ovarian carcinomas [50]. Our finding is in agreement with the study by Bhargava et al, 2008 who found that a monoclonal antibody to only K5 (clone 
XM26) was more sensitive than the K5/6 monoclonal antibodies (clones D5/16B4) in identifying basal-like breast carcinomas and reported a sensitivity of $97 \%$ for K5 but only 59\% for K5/6 [18]. The K5 antibody (clone EPR1600Y) used in our study is raised to a synthetic peptide in the head domain of keratin 5 whilst the K5/6 antibody clones were raised against purified keratin proteins. It has been suggested that the lower sensitivity

A

Progression-free survival

KRT5

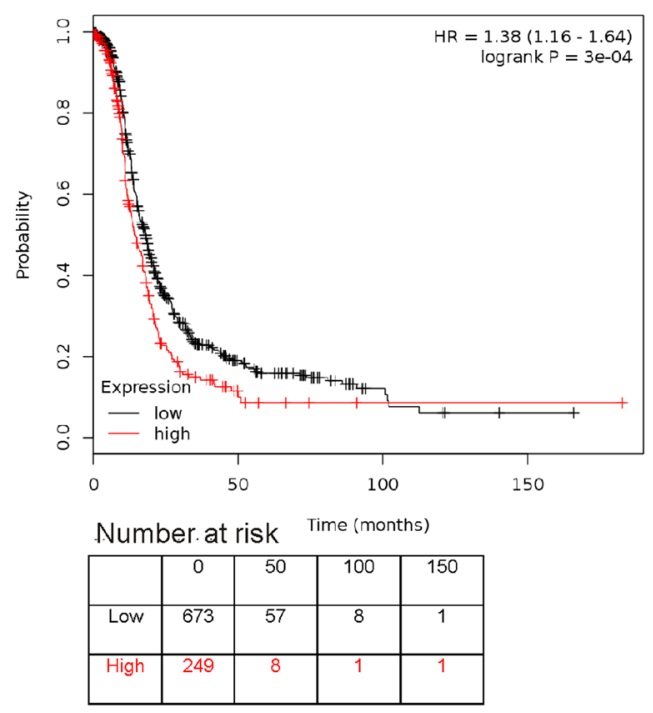

C

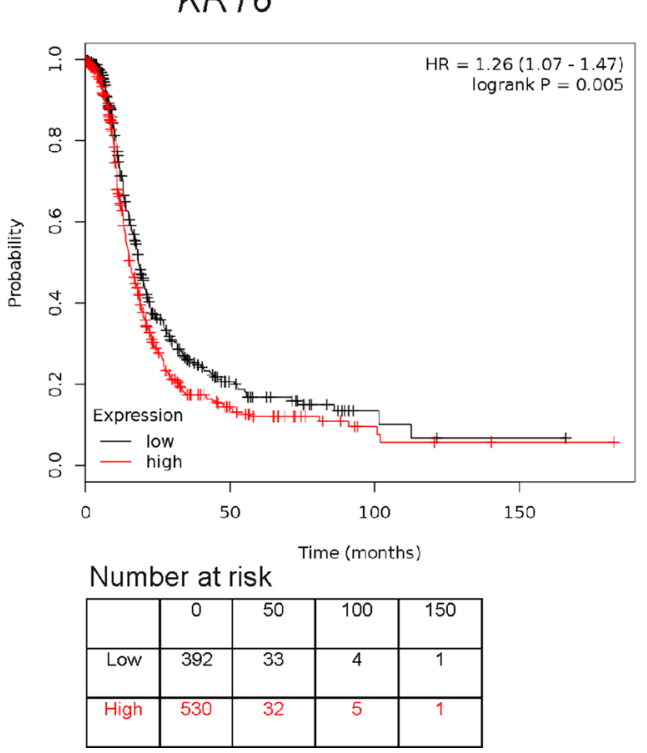

of the K5/6 antibodies by immunohistochemistry may be caused by an interference between each other's antigenic binding sites by steric hindrance [18].

Gene expression studies have previously identified only KRT5 mRNA and not KRT6 isoforms in normal breast and basal-like breast cancer in humans [11, 21, 51]. Consequently in normal breast tissues and cancer, the $\mathrm{K} 5 / 6$ antibody is thought to target only K5 [52]. We found

\section{B}

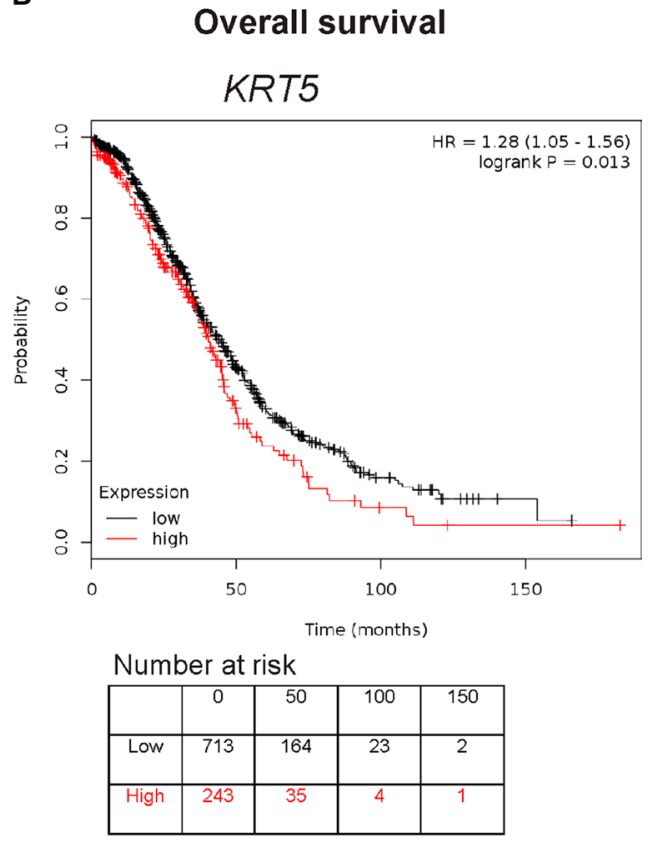

D

KRT6

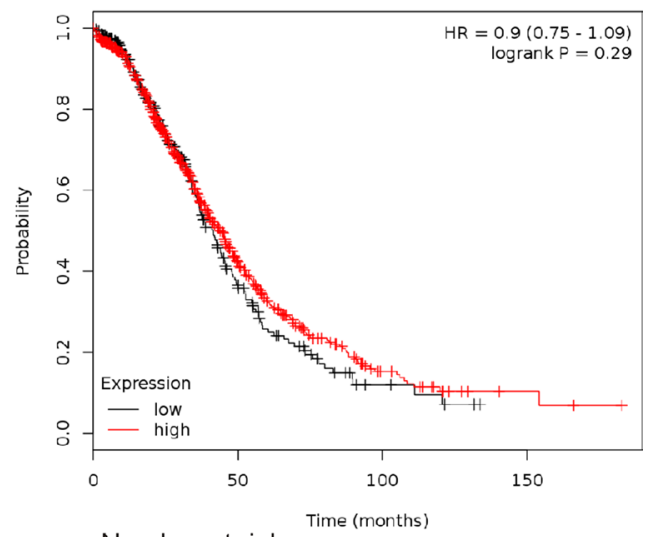

Number at risk

\begin{tabular}{|c|c|c|c|c|}
\hline & 0 & 50 & 100 & 150 \\
\hline Low & 271 & 54 & 6 & 0 \\
\hline High & 685 & 145 & 21 & 3 \\
\hline
\end{tabular}

Figure 3: Kaplan Meier survival analysis showing association of $K R T 5$ and $K R T 6$ mRNA expression with patient outcome. (A) Progression-free survival curve in stage III/IV serous ovarian cancers patients with low or high levels of KRT5 (Affymetrix probe set 201820_at). (B) Overall survival curve in stage III/IV serous ovarian cancers patients with low or high levels of KRT5 (Affymetrix probeset 201820_at). (C) Progression-free survival curve in stage III/IV serous ovarian cancers patients with low or high levels of KRT6 (Affymetrix probeset 209126_x_at, which detects all KRT6 isoforms). (D) Overall survival curve in stage III/IV serous ovarian cancers patients with low or high levels of KRT6 (Affymetrix probeset 209126_x_at, which detects all KRT6 isoforms). 
LP-9 peritoneal cells to express KRT6C but not KRT5. We confirmed that K6 protein is expressed in ovarian cancer cell lines and LP-9 cells but only faint K5 bands could be detected with K5/6 in OVCAR-5, OV-90 and SKOV-3 cell extracts. The low expression of $\mathrm{K} 5$ protein in ovarian cancer cell lines was confirmed by immunofluorescence as only $10-15 \%$ of ovarian cancer cells had detectable K5 protein without carboplatin treatment (see Figure 5C and 5D). The observed molecular weights of K5 (56 kDa) and K6 $(52 \mathrm{kDa})$ were close to the predicted molecular weight of $\mathrm{K} 5$ (62 kDa) and K6 (60 kDa), respectively, and consistent with previous studies that have observed $\mathrm{K} 5$ at $56 \mathrm{kDa}$ in rat liver cancer [53] and $\mathrm{K} 6$ at $50 \mathrm{kDa}$ in bladder cancer [54].

$\mathrm{K} 5 / \mathrm{K} 14$ form the main keratins in keratinocytes of stratified squamous epithelia of the epidermis as well as mucosal non-keratinizing stratified squamous epithelia [9]. K5 is strongly expressed in the undifferentiated basal cell layer which contains stem cells and is reduced in the differentiating suprabasal cell layers [7]. Our immunostaining in human skin using the $\mathrm{K} 5 / 6$ and K5 antibodies concur with this finding. Recent studies have reported that $\mathrm{K} 5 / \mathrm{K} 14$ modulates cell proliferation and cell differentiation in the stratified epithelia via the P13K/Akt pathway and K5/K14 negatively regulates cell differentiation via the Notch 1 signaling pathway [55]. Consequently K5/K14 is thought to play an important role in the maintenance of cell proliferation in the basal layer of stratified epithelia. It is likely that $\mathrm{K} 5$ regulates similar pathways in serous ovarian cancer cells.

Greater than $50 \%$ of $\mathrm{ER}^{+} \mathrm{PR}^{+}$tumors contain $\mathrm{ER}^{-}$ $\mathrm{PR}^{-} \mathrm{K}^{+}$subpopulations [26] and $\mathrm{K}^{+}$cells are increased in $\mathrm{ER}^{+}$breast tumors following treatment with neoadjuvant endocrine therapy [25]. ER-PR-K5 ${ }^{+}$luminal breast cancer cell populations, termed 'luminobasal' cells exhibiting enhanced progenitor properties can be induced by progestins, glucocorticoids, as well as mineralocorticoids
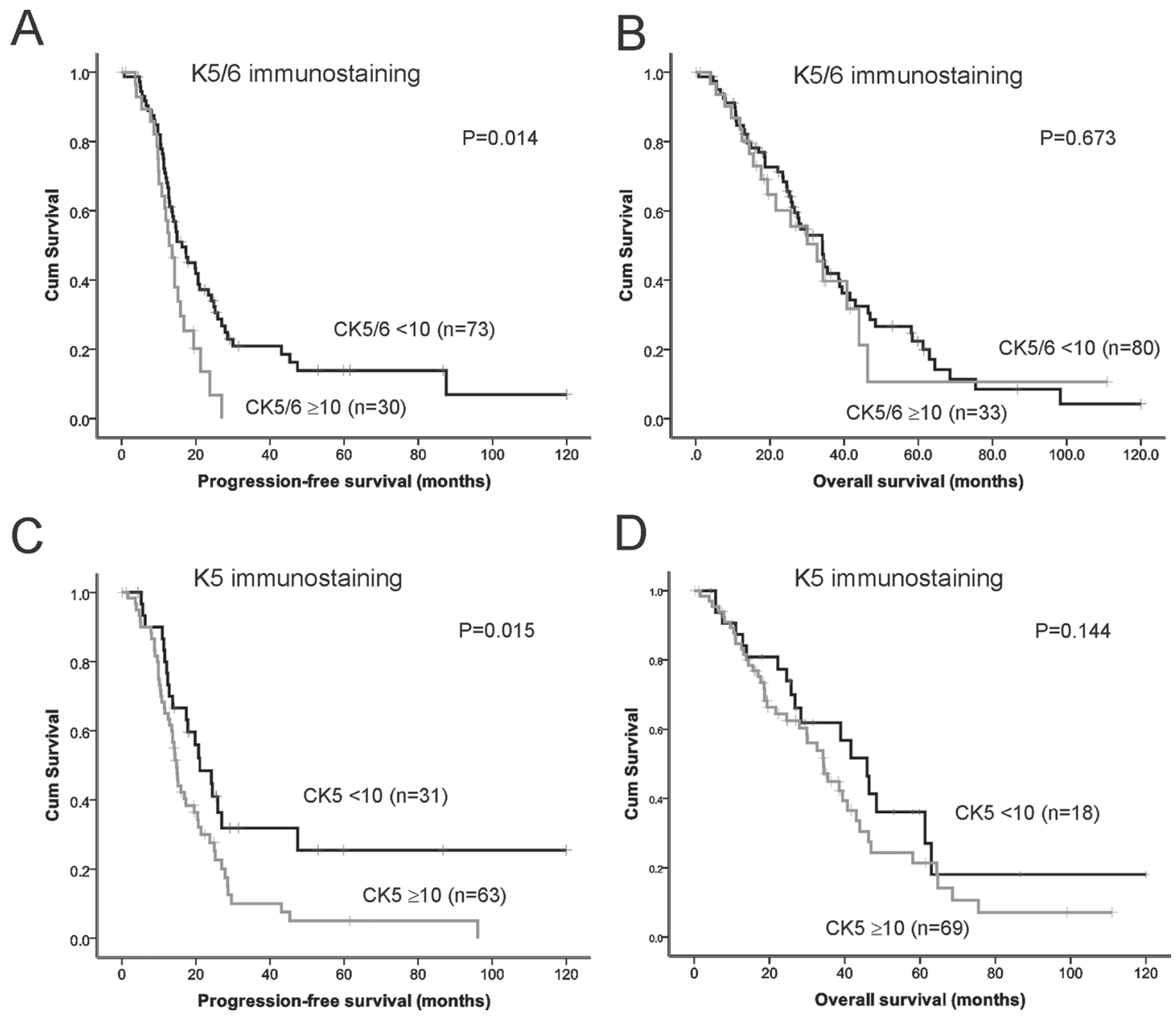

Figure 4: Kaplan Meier survival analysis showing association of expression of K5/6 and K5 alone with patient outcome. (A) Progression-free survival curve in stage III/IV serous ovarian cancers patients with high K5/6 immunostaining $(\geq 10 \%, n=30)$ and low K5/6 immunostaining $(<10 \%, n=73, P=0.014$, log rank test). (B) Overall survival curve in stage III/IV serous ovarian cancers patients with high $\mathrm{K} 5 / 6$ immunostaining $(>10 \%, n=33)$ and low $\mathrm{K} 5 / 6$ immunostaining $(<10 \%, n=80, P=0.673$, log rank test). $(\mathbf{C})$ Progression-free survival curve in stage III/IV serous ovarian cancers patients with high K5 immunostaining ( $\geq 10 \%, n=63)$ and low K5 immunostaining $(<10 \%, n=31, P=0.015$, log rank test). (D) Overall survival curve in stage III/IV serous ovarian cancers patients with high K5 immunostaining $(\geq 10 \%, n=69)$ and low $\mathrm{K} 5$ immunostaining $(<10 \%, n=18, P=0.144, \log$ rank test $)$. 
Table 2: Univariate cox regression analyses for progression-free survival and overall survival

Progression-free survival

Overall survival

\begin{tabular}{|c|c|c|c|c|c|c|c|}
\hline Variable & Relative risk & $95 \%$ CI & $P$ value & Variable & Relative risk & $95 \%$ CI & $P$ value \\
\hline $\begin{array}{c}\text { Age }^{\mathrm{a}} \\
(n=112)\end{array}$ & 1.23 & $0.80-1.90$ & 0.340 & Age $(n=120)$ & 1.25 & $0.79-1.97$ & 0.342 \\
\hline $\begin{array}{l}\text { Tumor stage }^{\mathrm{b}} \\
(n=112)\end{array}$ & 0.24 & $0.19-1.50$ & 0.540 & $\begin{array}{l}\text { Tumor stage } \\
(n=120)\end{array}$ & 0.52 & $0.26-1.99$ & 0.718 \\
\hline $\begin{array}{l}\text { Tumor grade }^{\mathrm{c}} \\
(n=112)\end{array}$ & 0.89 & $0.57-1.62$ & 0.962 & Tumor grade $(n=122)$ & 0.96 & $0.57-1.70$ & 0.985 \\
\hline $\begin{array}{l}\text { Residual } \\
\text { disease }^{\mathrm{d}} \\
(n=89)\end{array}$ & 1.47 & $0.75-2.88$ & 0.260 & $\begin{array}{l}\text { Residual disease } \\
\quad(n=96)\end{array}$ & 2.20 & $0.99-4.90$ & 0.053 \\
\hline $\begin{array}{c}\mathrm{K} 5 / 6^{\mathrm{e}} \\
(n=102)\end{array}$ & 1.78 & $1.01-2.66$ & 0.017 & $\mathrm{~K} 5 / 6(n=106)$ & 1.02 & $0.60-1.74$ & 0.929 \\
\hline $\begin{array}{c}\mathrm{K} 5^{\mathrm{f}} \\
(n=91)\end{array}$ & 1.90 & $1.12-3.19$ & 0.017 & $\begin{array}{c}\mathrm{K} 5 \\
(n=99)\end{array}$ & 1.40 & $0.82-2.44$ & 0.234 \\
\hline
\end{tabular}

NOTE: $P$ values highlighted in bold indicate $P<0.05$.

$\mathrm{a}=$ Age a dichotomous variable, cut point $<55 \mathrm{vs} \geq 55$.

$\mathrm{b}=$ Tumor stage (FIGO stage III vs FIGO stage IV).

$\mathrm{c}=$ Tumor grade (moderate vs poor).

$\mathrm{d}=$ Residual disease status (negative vs positive).

$\mathrm{e}=\mathrm{K} 5 / 6$ (\% positive cells) as a dichotomous variable, cut point $<10 \mathrm{vs} \geq 10$.

$\mathrm{f}=\mathrm{K} 5(\%$ positive cells $)$ as a dichotomous variable, cut point $<10 \mathrm{vs} \geq 10$.

$[26,56-58]$ and blocked by anti-progestins and prolactin [57]. Interestingly, these $\mathrm{K}^{+}$breast cancer cells were found to be less sensitive to 5-fluorouracil and docetaxel in in vitro culture and exhibited reduced apoptosis [25]. A recent study investigated metastasis formation in ovariectomized mice injected with luminal breast cancer cell lines and assessed the metastatic process following treatment with estradiol or estradiol + progestin [59]. The untreated ovariectomized mice were metastasis-free until they were supplemented with estradiol or estradiol + progestin. Unlike the parental cells that were predominately $\mathrm{ER}^{+} \mathrm{PR}^{+} \mathrm{K} 5^{-}$the metastases formed following estradiol or estradiol + progestin contained significantly increased proportions of ER-PR-K5 $5^{+}$cells (6-30\%). This finding may have important implications for women on hormonal contraception or replacement therapy who may harbor dormant $\mathrm{K}^{+}$micrometastases. It has also been suggested that basal-like breast cancers in BRCA1 deficient women may potentially arise from $\mathrm{K}^{+}$luminal progenitors [23]. Compounds that can effectively target these $\mathrm{K}^{+}$cells have the potential to improve the outcome of luminal breast cancers and basal-like breast cancers. Targeting $\mathrm{K}^{+}$cells may also be effective in reducing recurrence in patients with serous ovarian carcinoma. Indeed many similarities have been observed between basal-like breast cancers and serous ovarian carcinoma [60].

A recent study by Corr et al (2015) demonstrating that $\mathrm{K}^{+}$ovarian cancer cells were more resistant to cisplatin-induced apoptosis than $\mathrm{K}^{-}$cells has suggested that $\mathrm{K} 5$ is a marker of a chemoresistant subpopulation of ovarian cancer cells [50]. Their observation that the number of $\mathrm{K}^{+}$cells increased following cisplatin treatment agrees with the carboplatin data presented in our study. We additionally showed that K5 and K5/6 immunostaining is significantly increased following neoadjuvant chemotherapy treatment and that KRT5 mRNA is increased in chemoresistant compared to chemosensitive serous primary ovarian cancer. These findings support the notion that K5 plays an important role in the development chemotherapy resistance.

In conclusion, this study found for the first time that serous ovarian carcinomas with increased KRT5 and KRT6 mRNA expression, as well as increased $\mathrm{K} 5$ or $\mathrm{K} 5 / 6$ immunostaining have an increased risk of disease relapse. K5/6 and K5 expression may therefore be used for predicting the prognosis of serous ovarian cancer patients and to aid patient management. In addition our findings that $\mathrm{K} 5$ is increased following carboplatin treatment and in chemotherapy resistance cells suggest that K5 could also be used to identify cancer cells that are resistant to chemotherapy. Developing strategies to target K5 may prevent recurrence and chemotherapy resistance in serous ovarian cancer patients.

\section{MATERIALS AND METHODS}

\section{Cell culture}

The human ovarian cancer cell lines OVCAR-3, SKOV-3, and OV-90 were purchased from American Type Culture Collection (ATCC, VA, USA). OVCAR-5 

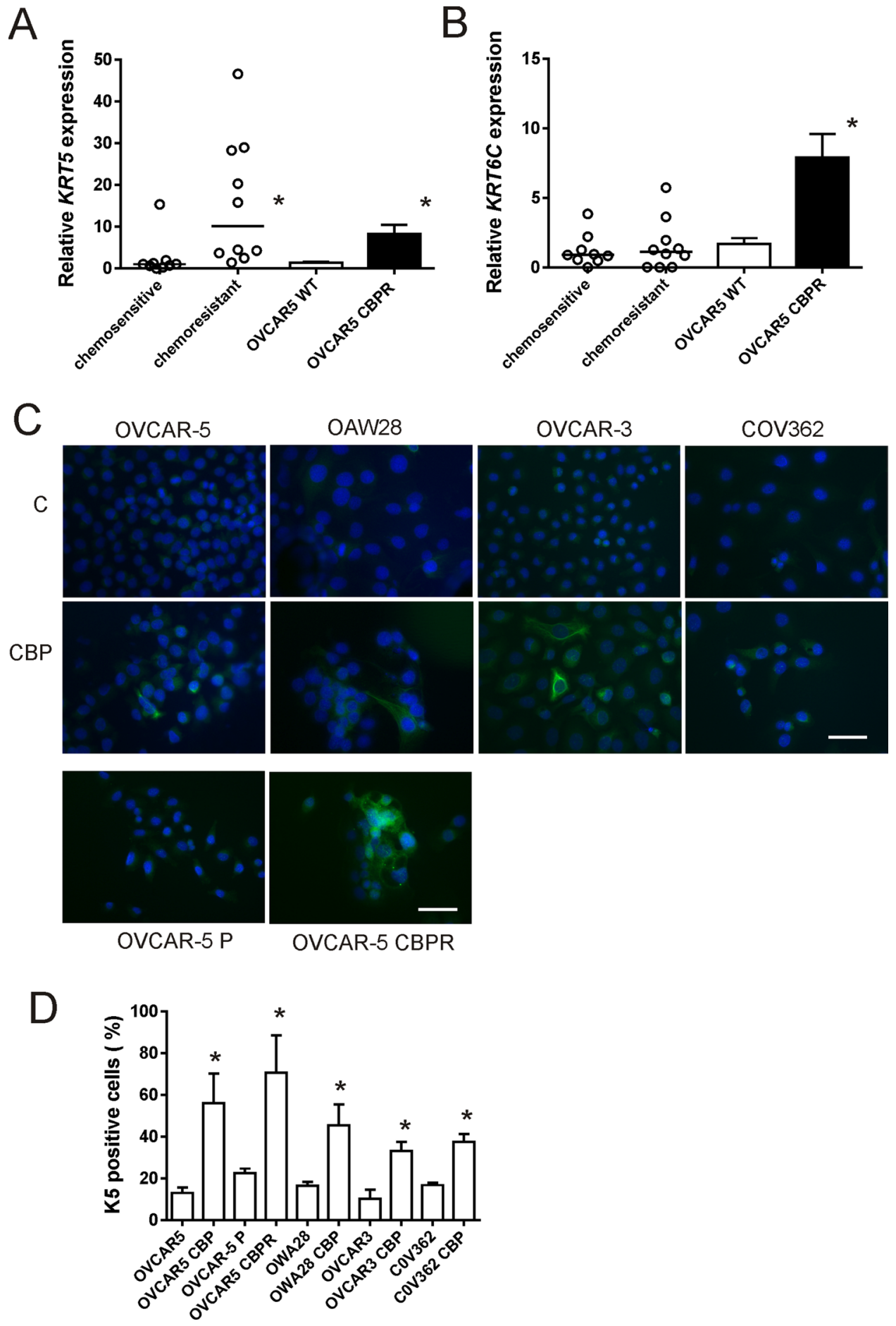

Figure 5: KRT5, KRT6C mRNA and K5 protein expression in serous ovarian cancer cell lines following chemotherapy treatment. $K R T 5(\mathbf{A})$ and $K R T 6 C(\mathbf{B})$ expression in chemotherapy resistant primary serous ovarian cancer cells $(n=10)$ compared to chemotherapy sensitive cells $(n=9)$ and OVCAR5 CBPR made resistant to carboplatin (CBP). KRT5 but not KRT6C was significantly increased in chemotherapy resistant cells $(n=10)$ compared to chemotherapy sensitive cells $(n=9, * P=0.0006$, Mann Whitney $U$ test). Both KRT5 (*P $<0.0001$, Mann Whitney $U$ test) and KRT6C ( ${ }^{*} P=0.0004$, Mann Whitney $U$ test $)$ were significantly increased in CBP resistant OVCAR-5 CBPR cells compared to parental OVCAR-5 cells. Data for the primary cells is expressed as the mean fold change from 3-6 RNA samples from 2 independent experiments. Data for OVCAR5 cells is expressed as the mean fold change \pm SEM from 10 individual RNA samples from 3 independent experiments. (C) K5 immunocytochemistry in serous ovarian cancer cells (OVCAR-5, OAW28, OVCAR-3 \& COV362) $\pm 48 \mathrm{hr}$ treatment with CBP IC F $_{50}$ and in parental OVCAR5 and CBP resistant OVCAR5 cells (OVCAR5 CBPR). (D) $\mathrm{K}^{+}$cells are increased following $48 \mathrm{hr}$ treatment with an $\mathrm{IC}_{50}$ dose of CBP and the development of chemoresistance. ${ }^{*} P<0.05$ (unpaired student $t$ test), data is expressed as mean \% positive cells \pm SEM from 3-4 independent experiments. 
cells were obtained from Dr Thomas Hamilton (Fox Chase Cancer Center, PA, USA) and the peritoneal cells, LP-9 were purchased from Coriell Cell Repositories (NJ, USA). COV362 and OAW28 were purchased from the European Collection of Cell culture (ECCC). OV-90, OVCAR-3, SKOV-3 and OVCAR-5 cell lines were grown in RPMI 1640 media (cat no. R8758, Sigma Adrich, St Louis, USA) whilst COV362 and OAW28 were grown in DMEM media (cat no. 10567-022, Gibco, Life Technologies, Mulgrave, Vic, Australia). All cell lines are cultured with $10 \%$ fetal bovine serum (Sigma Aldrich) and maintained at $37^{\circ} \mathrm{C}$ in an environment of 5\% $\mathrm{CO}_{2}$. OVCAR-5 cells were made resistant to carboplatin (OVCAR-5 CBPR) following treatment with 8 cycles of carboplatin (CBP, $50 \mu \mathrm{M}$, Hospira Australia Pty, Ltd). The OVCAR-5 CBPR cells exhibited an $\mathrm{IC}_{50}(273 \mu \mathrm{M})$ to carboplatin that was nearly 3-fold higher than that for the parental OVCAR-5 cells $(99 \mu \mathrm{M})$ (data not shown)

Primary ovarian cancer cells were derived from ascites collected from serous ovarian cancer patients after informed consent and with approval of the Royal Adelaide Hospital Human Ethics Committee as described previously [61]. All primary cells were grown in Advanced RPMI 1640 medium (cat no 12633-020) supplemented with 4 mM L-glutamine, 10\% FBS (Sigma Aldrich, St Louis, MO, USA) and antibiotics (100 U penicillin G, $100 \mu \mathrm{g} / \mathrm{ml}$ streptomycin sulfate and $100 \mu \mathrm{g} / \mathrm{ml}$ amphotericin B, Sigma Aldrich). Methods were carried out in accordance with the approved guidelines. The clinicopathological characteristics of the patients whose ascites was used to isolate the primary cells are shown in Supplementary Table 2.

\section{Quantitative real-time PCR}

Cells were plated at 5,000 cells in 96 well plates and cultured until confluence for 72-96 hr. Total RNA was isolated and reverse transcribed using the TaqMan ${ }^{\circledR}$ Gene expression Cells-to- $\mathrm{CT}^{\mathrm{TM}}$ kit (Applied Biosystems, Mulgrave, Victoria, Australia), as per the manufacturer's instructions. Briefly, lysis solution with DNAse was added to each well and incubated for $5 \mathrm{~min}$ at room temperature. Stop solution was then added to each well and mixed. The lysate $(10 \mu \mathrm{l})$ was added to a $40 \mu \mathrm{l}$ reverse transcription master mix and reverse transcribed for $1 \mathrm{hr}$. Resultant cDNA was stored as $50 \mu$ l aliquots at $-20^{\circ} \mathrm{C}$ for qRTPCR analysis. qRT-PCR reactions were performed on triplicate samples using TaqMan ${ }^{\circledR}$ primer sets for KRT5 (Hs00361185_m1), KRT6C (Hs00752476_s1) using the Quantstudio 12K Flex Real Time PCR System (Applied Biosystems). Briefly, PCR reactions were made up to $10 \mu \mathrm{l}$ and contained TaqMan ${ }^{\circledR}$ Gene Expression Master Mix (2×), primers for the gene of interest, nuclease free water, and the sample cDNA. PCR cycling conditions were as follows: $50^{\circ} \mathrm{C}$ for $2 \mathrm{~min}, 95^{\circ} \mathrm{C}$ for $10 \mathrm{~min}$ (with 40 cycles following of $95^{\circ} \mathrm{C}$ for $15 \mathrm{sec}$ ), and $60^{\circ} \mathrm{C}$ for $1 \mathrm{~min}$. $\mathrm{CT}$ values were normalised to the house keeping gene $\beta$-actin (Human ACTB 4333762, Applied Biosystems) and calibrator using the $2^{-\Delta \Delta \mathrm{CT}}$ method.

\section{Western immunoblotting}

OVCAR-5, OVCAR-3, OV-90, SKOV-3, and LP-9 cells a were grown to $80 \%$ confluence in $75 \mathrm{~cm}^{2}$ flasks (Corning, Sigma Aldrich) and cell extracts were collected. Cells were dislodged using a cell scraper and resuspended in $200 \mu \mathrm{l}$ of RIPA buffer ( $1 \%$ Nonidet P-40, $1 \%$ sodium deoxycholate, $0.1 \% \mathrm{SDS}, 0.15 \mathrm{M}$ sodium chloride, $50 \mathrm{mM}$ Tris- HCL and $1 \mathrm{mM}$ EDTA, pH 8.0 with protease inhibitor) and spun at $7000 \mathrm{rpm}$ (Eppendorf 5424 centrifuge) for $10 \mathrm{~min}$ and stored at $-20^{\circ} \mathrm{C}$. Equal amounts of protein were electrophoresed and transferred to PVDF membranes (GE Healthcare, Little Chalfont, England) as described previously [3]. Proteins bands were detected with mouse monoclonal K5/6 antibody (1/200, clone D5/16 B4, Dako, Glostrup, Denmark) or K5 rabbit monoclonal antibody (1/5000, clone EPR1600Y, Abcam Ab75869, Melbourne, Vic, Australia) with anti-mouse or anti-rabbit IgG peroxidase-conjugated secondary antibodies, enhanced chemiluminescence, and autoradiography as described previously [3]. $\beta$-actin mouse monoclonal antibody $(1 / 10,000$, clone AC- 15 , Sigma Aldrich A3854) was used as a loading control. Ovarian cancer tissue extracts prepared in RIPA buffer with high $\mathrm{K} 5 / 6$ and $\mathrm{K} 5$ immunostaining used as positive controls for the western blots.

\section{Tissue cohort}

Tissue sections were obtained from formalin fixed paraffin embedded blocks from normal ovaries $(n=8)$, benign serous tumors $(n=8)$, serous borderline tumors $(n=10)$, and primary advanced stage (FIGO stage III/ IV) serous ovarian cancers $(n=126)$. The cancer tissues were assembled into tissue microarrays (TMAs, $1 \mathrm{~mm}$ triplicate cores) from archived tissue (cancer areas identified by pathologist, AR) obtained from serous ovarian cancer patients diagnosed between 1988 and 2012. An additional 21 tissues were obtained from patients with high grade serous cancer after they had received neoadjuvent chemotherapy. Approval was obtained from the Royal Adelaide Hospital Human Ethics Committee and methods were carried out in accordance with the approved guidelines. Detailed pathological and clinical characteristics of the patient samples are summarized in Supplementary Table 3.

\section{Analysis of public databases}

The Kaplan-Meier plotter tool (http://kmplot. com/analysis/) was used to generate survival curves combining KRT5 (Affymetrix probe 201820_at) and KRT6 (Affymetrix probe 209126_x_at detects all KRT6 
isoforms) mRNA data from 13 public ovarian cancer datasets [31]. The Kaplan-Meier analysis was performed on the 2015 version database $(n=1648)$ and patients were split by the best cut-off selected by the online plotter tool [31]. PFS and OS data was available for 922 and 956 stage III/IV serous ovarian cancer patients, respectively. cBioPortal (http://www.cbioportal.org/) was used to assess correlations between KRT5 and KRT6 expression levels with clinicopathological parameters features in the TCGA 2011 dataset $[62,63]$.

\section{Immunohistochemistry}

Immunohistochemistry was performed as previously described [64]. Briefly, tissue sections $(5 \mu \mathrm{m})$ underwent microwave antigen retrieval for 10 minutes at $100^{\circ} \mathrm{C}$ in a steam microwave (Sixth Sense, Whirlpool, VIC, Australia) in $10 \mathrm{mM}$ Tris buffer, $1 \mathrm{mM}$ EDTA (pH 9.0). Sections were incubated overnight with mouse monoclonal antibody which detects both $\mathrm{K} 5$ and $\mathrm{K} 6$ (1/50, clone D5/16 B4, Dako) or K5 rabbit monoclonal antibody (1/400, clone EPR1600Y, Abcam Ab75869), in blocking buffer (5\% normal goat serum) at $4^{\circ} \mathrm{C}$. Visualization of immunoreactivity was achieved using biotinylated anti-mouse or anti-rabbit immunoglobulins streptavidin-peroxidase conjugate, diaminobenzidine substrate as described previously [3]. Human skin was used as a positive control and negative controls included tissues incubated with no primary antibody or with mouse or rabbit immunoglobulins. Slides were digitally scanned using the NanoZoomer Digital Pathology System (Hamamatsu Photonics, SZK, Japan) and images were collected using NDP view imaging software (NDP scan software v2.2, Hamamatsu Photonics). K5/6 or K5 expression was quantified using a visual grading system based on the extent of staining. Percentage of positive tumor cells was graded on a scale from $0-3 ; 0=$ none, $1=1-9 \%, 2=10-50 \%, 3=>50 \%$ by two independent assessors used previously for breast cancer [65, 66]. High K5/6 or K5 immunostaining was defined as $\geq 10 \%$ positivity and $<10 \%$ was defined as low K5/6 or K5 immunostaining.

\section{Immunocytochemistry}

Ovarian cancer cells $\left(2 \times 10^{4}\right.$ cells/well $)$ were plated in 8 well tissue culture chamber slides (Nunclon ${ }^{\mathrm{TM}}$ LabTek II Chamber slide, RS Glass Slide, Naperville, IL) in $500 \mu 110 \%$ FBS RPMI for $24 \mathrm{~h}$ and treated for $48 \mathrm{~h}$ with $\mathrm{IC}_{50}$ concentration of $\mathrm{CBP}$ or control media. $\mathrm{CBP}$ $\mathrm{IC}_{50}$ for serous ovarian cancer cell lines were previously determined to be $\sim 100 \mu \mathrm{M}$ for OVCAR-5, OVCAR-3 and OAW28 cells and $500 \mu \mathrm{M}$ for COV362 cells. Cells were fixed with cold 100\% methanol (5 min) and cold $100 \%$ acetone (3 min), washed with PBS and blocked with 5\% goat serum and incubated overnight with rabbit monoclonal K5 (1/50, clone EPR1600Y, Abcam Ab75869). K5 was visualized with goat anti-rabbit Alexa Fluor $^{\circledR} 488(1 / 200,1 \mathrm{hr}$ at RT, catalogue no. A11034, Molecular Probes, Life Technologies) and slides were mounted with Prolong Gold Antifade Mountant with Dapi (catalogue no. P36941, Molecular Probes, Life Technologies). Cells were viewed with an epifluorescence microscope (BX50, Olympus Australia) and imaged using a $40 \times$ objective and a Spot RT digital camera (Diagnostic Instruments, Sterling Heights, MI). Negative controls included rabbit immunoglobulin or no primary antibody. The percentage of $\mathrm{K}^{+}$cells in controls and following carboplatin treatment were evaluated in 5 high power images ( 100-200 cells).

\section{Statistical analyses}

All statistical analyses were performed using SPSS for Windows software (Version 21.0, SPSS Inc., Chicago, IL, USA). Chi-squared test was performed to determine the correlation of $\mathrm{K} 5 / 6$ immunostaining in ovarian tumor tissues with clinical and pathological parameters. The Mann Whitney $U$ test was used to assess differences between KRT5 and KRT6C expression in the chemotherapy sensitive and chemotherapy resistant primary serous ovarian cancer cells and the parental OVCAR-5 and carboplatin resistant OVCAR-5 CBPR cells. The one way ANOVA with the Dunnet C Post hoc test was used to assess differences between $\mathrm{Z}$ scores for KRT5 and KRT6 expression and clinical parameters as data was normally distributed. Kaplan-Meier and univariate Cox Regression analyses were performed to assess the association of $\mathrm{K} 5 / 6$ expression in the advanced stage ovarian cancer TMA cohort with PFS and OS. Relapse or death due to ovarian cancer was used as the endpoint to determine whether KRT5, or KRT6C expression and $\mathrm{K} 5 / 6$ positivity was associated with PFS or OS. Statistical significance was accepted at $P<0.05$.

\section{Abbreviations}

CBP, carboplatin CM, conditioned media; HR; hazard ratio, PFS, progression-free survival; OSE, ovarian surface epithelium; OS, overall survival; TMA, tissue microarray.

\section{ACKNOWLEDGMENTS AND FUNDING}

We thank Dr. Thomas Hamilton (Fox Chase Cancer Center, Philadelphia, PA) for kindly providing the OVCAR-5 cell line, Mrs Wendy Bonner, Ms Rachel Ho, Ms Hongmei Xie and Ms Zoe Price for their help with the K5/6 and K5 immunostaining. This research has been funded by the Ovarian Cancer Research Foundation (OCRF), Australia and the Cancer Council South Australia's Beat Cancer Project on behalf of its donors 
and the State Government of South Australia through the Department of Health. CR is currently supported by the Lin Huddleston Ovarian Cancer Fellowship funded by the Cancer Council South Australia and the School of Medicine, University of Adelaide.

\section{CONFLICTS OF INTEREST}

None.

\section{REFERENCES}

1. Torre LA, Bray F, Siegel RL, Ferlay J, Lortet-Tieulent J, Jemal A. Global cancer statistics, 2012. CA Cancer J Clin. 2015; 65:87-108.

2. Coleman RL, Monk BJ, Sood AK, Herzog TJ. Latest research and treatment of advanced-stage epithelial ovarian cancer. Nat Rev Clin Oncol. 2013; 10:211-224.

3. Ween MP, Lokman NA, Hoffmann P, Rodgers RJ, Ricciardelli C, Oehler MK. Transforming growth factorbeta-induced protein secreted by peritoneal cells increases the metastatic potential of ovarian cancer cells. Int J Cancer. 2011; 128:1570-1584.

4. Lokman NA, Elder AS, Ween MP, Pyragius CE, Hoffmann P, Oehler MK, Ricciardelli C. Annexin A2 is regulated by ovarian cancer-peritoneal cell interactions and promotes metastasis. Oncotarget. 2013; 4:1199-1211. doi: 10.18632/oncotarget.1122.

5. Ricciardelli C, Lokman NA, Ween MP, Oehler M. Ovarian cancer-peritoneal cell interactions promote extracellular matrix processing. Endocr Relat Cancer. 2016; 23, T155-T168.

6. Pallari HM, Eriksson JE. Intermediate filaments as signaling platforms. Sci STKE. 2006; 2006:pe53.

7. Moll R, Divo M, Langbein L. The human keratins: biology and pathology. Histochem Cell Biol. 2008; 129:705-733.

8. Karantza V. Keratins in health and cancer: more than mere epithelial cell markers. Oncogene. 2011; 30:127-138.

9. Moll R, Franke WW, Schiller DL, Geiger B, Krepler R. The catalog of human cytokeratins: patterns of expression in normal epithelia, tumors and cultured cells. Cell. 1982; 31:11-24.

10. Gusterson BA, Ross DT, Heath VJ, Stein T. Basal cytokeratins and their relationship to the cellular origin and functional classification of breast cancer. Breast Cancer Res. 2005; 7:143-148.

11. Bocker W, Moll R, Poremba C, Holland R, Van Diest PJ, Dervan P, Burger H, Wai D, Ina Diallo R, Brandt B, Herbst H, Schmidt A, Lerch MM, et al. Common adult stem cells in the human breast give rise to glandular and myoepithelial cell lineages: a new cell biological concept. Lab Invest. 2002; 82:737-746.

12. Yamany T, Van Batavia J, Mendelsohn C. Formation and regeneration of the urothelium. Curr Opin Organ Transplant. 2014; 19:323-330.
13. Rogers MA, Edler L, Winter H, Langbein L, Beckmann I, Schweizer J. Characterization of new members of the human type II keratin gene family and a general evaluation of the keratin gene domain on chromosome 12q13.13. J Invest Dermatol. 2005; 124:536-544.

14. Schweizer J, Bowden PE, Coulombe PA, Langbein L, Lane EB, Magin TM, Maltais L, Omary MB, Parry DA, Rogers MA, Wright MW. New consensus nomenclature for mammalian keratins. J Cell Biol. 2006; 174:169-174.

15. Grimm SL, Bu W, Longley MA, Roop DR, Li Y, Rosen JM. Keratin 6 is not essential for mammary gland development. Breast Cancer Res. 2006; 8:R29.

16. Schmelz M, Moll R, Hesse U, Prasad AR, Gandolfi JA, Hasan SR, Bartholdi M, Cress AE. Identification of a stem cell candidate in the normal human prostate gland. Eur J Cell Biol. 2005; 84:341-354.

17. Abd El-Rehim DM, Pinder SE, Paish CE, Bell J, Blamey RW, Robertson JF, Nicholson RI, Ellis IO. Expression of luminal and basal cytokeratins in human breast carcinoma. J Pathol. 2004; 203:661-671.

18. Bhargava R, Beriwal S, McManus K, Dabbs DJ. CK5 is more sensitive than CK5/6 in identifying the "basal-like" phenotype of breast carcinoma. Am J Clin Pathol. 2008; 130:724-730.

19. Nielsen TO, Hsu FD, Jensen K, Cheang M, Karaca G, $\mathrm{Hu}$ Z, Hernandez-Boussard T, Livasy C, Cowan D, Dressler L, Akslen LA, Ragaz J, Gown AM, et al. Immunohistochemical and clinical characterization of the basal-like subtype of invasive breast carcinoma. Clin Cancer Res. 2004; 10:5367-5374.

20. Liu H, Fan Q, Zhang Z, Li X, Yu H, Meng F. Basal-HER2 phenotype shows poorer survival than basal-like phenotype in hormone receptor-negative invasive breast cancers. Human Pathol. 2008; 39:167-174.

21. Moll R. Cytokeratins as markers of differentiation in the diagnosis of epithelial tumors. Sub-cellular Biochem. 1998; 31:205-262.

22. Chu PG, Weiss LM. Expression of cytokeratin 5/6 in epithelial neoplasms: an immunohistochemical study of 509 cases. Mod Pathol. 2002; 15:6-10.

23. Lim E, Vaillant F, Wu D, Forrest NC, Pal B, Hart AH, Asselin-Labat ML, Gyorki DE, Ward T, Partanen A, Feleppa F, Huschtscha LI, Thorne HJ, et al. Aberrant luminal progenitors as the candidate target population for basal tumor development in BRCA1 mutation carriers. Nature Med. 2009; 15:907-913.

24. Horwitz KB, Dye WW, Harrell JC, Kabos P, Sartorius CA. Rare steroid receptor-negative basal-like tumorigenic cells in luminal subtype human breast cancer xenografts. Proc Natl Acad Sci U S A. 2008; 105:5774-5779.

25. Kabos P, Haughian JM, Wang X, Dye WW, Finlayson C, Elias A, Horwitz KB, Sartorius CA. Cytokeratin 5 positive cells represent a steroid receptor negative and therapy resistant subpopulation in luminal breast cancers. Breast Cancer Res Treat. 2011; 128:45-55. 
26. Haughian JM, Pinto MP, Harrell JC, Bliesner BS, Joensuu KM, Dye WW, Sartorius CA, Tan AC, Heikkila P, Perou CM, Horwitz KB. Maintenance of hormone responsiveness in luminal breast cancers by suppression of Notch. Proc Natl Acad Sci USA. 2012; 109:2742-2747.

27. Wauters CC, Smedts F, Gerrits LG, Bosman FT, Ramaekers FC. Keratins 7 and 20 as diagnostic markers of carcinomas metastatic to the ovary. Hum Pathol. 1995; 26:852-855.

28. Wang YF, Lang HY, Yuan J, Wang J, Wang R, Zhang XH, Zhang J, Zhao T, Li YR, Liu JY, Zeng LH, Guo GZ. Overexpression of keratin 17 is associated with poor prognosis in epithelial ovarian cancer. Tumour Biol. 2013; 34:1685-1689.

29. Tempfer C, Hefler L, Heinzl H, Loesch A, Gitsch G, Rumpold H, Kainz C. CYFRA 21-1 serum levels in women with adnexal masses and inflammatory diseases. Brit J Cancer. 1998; 78:1108-1112.

30. Liu M, Mor G, Cheng H, Xiang X, Hui P, Rutherford T, Yin G, Rimm DL, Holmberg J, Alvero A, Silasi DA. High frequency of putative ovarian cancer stem cells with CD44/CK19 coexpression is associated with decreased progression-free intervals in patients with recurrent epithelial ovarian cancer. Reprod Sci. 2013; 20:605-615.

31. Gyorffy B, Lanczky A, Szallasi Z. Implementing an online tool for genome-wide validation of survival-associated biomarkers in ovarian-cancer using microarray data from 1287 patients. Endocr Relat Cancer. 2012; 19:197-208.

32. Colombo PE, Fabbro M, Theillet C, Bibeau F, Rouanet P, Ray-Coquard I. Sensitivity and resistance to treatment in the primary management of epithelial ovarian cancer. Crit Rev Oncol Hematol. 2014; 89:207-16.

33. Markey AC, Lane EB, Macdonald DM, Leigh IM. Keratin expression in basal cell carcinomas. British J Dermatol. 1992; 126:154-160.

34. Abrahams NA, Ormsby AH, Brainard J. Validation of cytokeratin 5/6 as an effective substitute for keratin 903 in the differentiation of benign from malignant glands in prostate needle biopsies. Histopathol. 2002; 41:35-41.

35. Wang W, Bergh A, Damber JE. Morphological transition of proliferative inflammatory atrophy to high-grade intraepithelial neoplasia and cancer in human prostate. Prostate. 2009; 69:1378-1386.

36. Ribeiro-Silva A, Ramalho LN, Garcia SB, Brandao DF, Chahud F, Zucoloto S. p63 correlates with both BRCA1 and cytokeratin 5 in invasive breast carcinomas: further evidence for the pathogenesis of the basal phenotype of breast cancer. Histopathol. 2005; 47:458-466.

37. Mohammadizadeh F, Naimi A, Rajabi P, Ghasemibasir H, Eftekhari A. Expression of basal and luminal cytokeratins in breast cancer and their correlation with clinicopathological prognostic variables. Indian J Med Sci. 2009; 63:152-162.

38. Kuo WH, Chang YY, Lai LC, Tsai MH, Hsiao CK, Chang KJ, Chuang EY. Molecular characteristics and metastasis predictor genes of triple-negative breast cancer: a clinical study of triple-negative breast carcinomas. PloS one. 2012; 7:e45831.

39. Moran CA, Albores-Saavedra J, Suster S. Primary peritoneal mesotheliomas in children: a clinicopathological and immunohistochemical study of eight cases. Histopathol. 2008; 52:824-830.

40. Ismail HM, Nouh MA, Abulkheir IL, Abd El-Rahman Ael R, Tawfik HN. Pleural mesothelioma: diagnostic problems and evaluation of prognostic factors. J Egypt Natl Canc Inst. 2006; 18:303-310.

41. Miettinen M, Sarlomo-Rikala M. Expression of calretinin, thrombomodulin, keratin 5, and mesothelin in lung carcinomas of different types: an immunohistochemical analysis of 596 tumors in comparison with epithelioid mesotheliomas of the pleura. Am J Surg Pathol. 2003; 27:150-158.

42. Bhalla A, Manjari M, Kahlon SK, Kumar P, Kalra N. Cytokeratin 5/6 expression in benign and malignant breast lesions. Indian J Pathol Microbiol. 2010; 53:676-680.

43. Inanc M, Ozkan M, Karaca H, Berk V, Bozkurt O, Duran AO, Ozaslan E, Akgun H, Tekelioglu F, Elmali F. Cytokeratin 5/6, c-Met expressions, and PTEN loss prognostic indicators in triple-negative breast cancer. Med Oncol. 2014; 31:801.

44. Ring BZ, Seitz RS, Beck RA, Shasteen WJ, Soltermann A, Arbogast S, Robert F, Schreeder MT, Ross DT. A novel fiveantibody immunohistochemical test for subclassification of lung carcinoma. Mod Pathol. 2009; 22:1032-1043.

45. Ko CJ, Leffell DJ, McNiff JM. Adenosquamous carcinoma: a report of nine cases with p63 and cytokeratin 5/6 staining. J Cutan Pathol. 2009; 36:448-452.

46. Khayyata S, Yun S, Pasha T, Jian B, McGrath C, Yu G, Gupta P, Baloch Z. Value of P63 and CK5/6 in distinguishing squamous cell carcinoma from adenocarcinoma in lung fine-needle aspiration specimens. Diagn Cytopathol. 2009; 37:178-183.

47. Van Batavia J, Yamany $T$, Molotkov A, Dan H, Mansukhani M, Batourina E, Schneider K, Oyon D, Dunlop M, Wu XR, Cordon-Cardo C, Mendelsohn C. Bladder cancers arise from distinct urothelial subpopulations. Nat Cell Biol. 2014; 16:982-991, 981-985.

48. Ordonez NG. The diagnostic utility of immunohistochemistry and electron microscopy in distinguishing between peritoneal mesotheliomas and serous carcinomas: a comparative study. Mod Pathol. 2006; 19:34-48.

49. Nofech-Mozes S, Khalifa MA, Ismiil N, Saad RS, Hanna WM, Covens A, Ghorab Z. Immunophenotyping of serous carcinoma of the female genital tract. Mod Pathol. 2008; 21:1147-1155.

50. Corr BR, Finlay-Schultz J, Rosen RB, Qamar L, Post MD, Behbakht K, Spillman MA, Sartorius CA. Cytokeratin 5-Positive Cells Represent a Therapy Resistant subpopulation in Epithelial Ovarian Cancer. Int J Gynecol Cancer. 2015; 25:1565-1573. 
51. Perou CM, Sorlie T, Eisen MB, van de Rijn M, Jeffrey SS, Rees CA, Pollack JR, Ross DT, Johnsen H, Akslen LA, Fluge O, Pergamenschikov A, Williams C, et al. Molecular portraits of human breast tumours. Nature. 2000; 406:747-752.

52. Rakha EA, El-Sayed ME, Reis-Filho J, Ellis IO. Pathobiological aspects of basal-like breast cancer. Breast Cancer Res Treat. 2009; 113:411-422.

53. Barboro P, D'Arrigo C, Repaci E, Bagnasco L, Orecchia P, Carnemolla B, Patrone E, Balbi C. Proteomic analysis of the nuclear matrix in the early stages of rat liver carcinogenesis: identification of differentially expressed and MAR-binding proteins. Exp Cell Res. 2009; 315:226-239.

54. Ostergaard M, Rasmussen HH, Nielsen HV, Vorum H, Orntoft TF, Wolf H, Celis JE. Proteome profiling of bladder squamous cell carcinomas: identification of markers that define their degree of differentiation. Cancer Res. 1997; 57:4111-4117.

55. Alam H, Sehgal L, Kundu ST, Dalal SN, Vaidya MM. Novel function of keratins 5 and 14 in proliferation and differentiation of stratified epithelial cells. Mol Biol Cell. 2011; 22:4068-4078.

56. Axlund SD, Yoo BH, Rosen RB, Schaack J, Kabos P, Labarbera DV, Sartorius CA. Progesterone-inducible cytokeratin 5-positive cells in luminal breast cancer exhibit progenitor properties. Horm Cancer. 2013; 4:36-49.

57. Sato $\mathrm{T}$, Tran TH, Peck AR, Girondo MA, Liu C, Goodman CR, Neilson LM, Freydin B, Chervoneva I, Hyslop T, Kovatich AJ, Hooke JA, Shriver CD, et al. Prolactin suppresses a progestin-induced CK5-positive cell population in luminal breast cancer through inhibition of progestin-driven BCL6 expression. Oncogene. 2014; 33:2215-2224.

58. Goodman CR, Sato T, Peck AR, Girondo MA, Yang N, Liu C, Yanac AF, Kovatich AJ, Hooke JA, Shriver CD, Mitchell EP, Hyslop T, Rui H. Steroid induction of therapy-resistant cytokeratin-5-positive cells in estrogen receptor-positive breast cancer through a BCL6-dependent mechanism. Oncogene. 2016; 35:1373-1385.

59. Ogba N, Manning NG, Bliesner BS, Ambler S, Haughian JM, Pinto MP, Jedlicka P, Joensuu K, Heikkila P,
Horwitz KB. Luminal breast cancer metastases and tumor arousal from dormancy are promoted by direct actions of estradiol and progesterone on the malignant cells. Breast Cancer Res. 2014; 16:489.

60. Jonsson JM, Johansson I, Dominguez-Valentin M, Kimbung S, Jonsson M, Bonde JH, Kannisto P, Masback A, Malander S, Nilbert M, Hedenfalk I. Molecular subtyping of serous ovarian tumors reveals multiple connections to intrinsic breast cancer subtypes. PloS one. 2014; 9:e107643.

61. Ricciardelli C, Lokman NA, Cheruvu S, Tan IA, Ween MP, Pyragius CE, Ruszkiewicz A, Hoffmann P, Oehler MK. Transketolase is upregulated in metastatic peritoneal implants and promotes ovarian cancer cell proliferation. Clin Exp Metastasis. 2015; 32:441-455.

62. Gao J, Aksoy BA, Dogrusoz U, Dresdner G, Gross B, Sumer SO, Sun Y, Jacobsen A, Sinha R, Larsson E, Cerami E, Sander C, Schultz N. Integrative analysis of complex cancer genomics and clinical profiles using the cBioPortal. Sci Signal. 2013; 6:pl1.

63. Cerami E, Gao J, Dogrusoz U, Gross BE, Sumer SO, Aksoy BA, Jacobsen A, Byrne CJ, Heuer ML, Larsson E, Antipin Y, Reva B, Goldberg AP, et al. The cBio cancer genomics portal: an open platform for exploring multidimensional cancer genomics data. Cancer Discov. 2012; 2:401-404.

64. Lokman NA, Elder AS, Ricciardelli C, Oehler MK. Chick Chorioallantoic Membrane (CAM) Assay as an In Vivo Model to Study the Effect of Newly Identified Molecules on Ovarian Cancer Invasion and Metastasis. Int J Mol Sci. 2012; 13:9959-9970.

65. Otterbach F, Bankfalvi A, Bergner S, Decker T, Krech R, Boecker W. Cytokeratin 5/6 immunohistochemistry assists the differential diagnosis of atypical proliferations of the breast. Histopathol. 2000; 37:232-240.

66. Martin-Castillo B, Lopez-Bonet E, Buxo M, Dorca J, Tuca-Rodriguez F, Ruano MA, Colomer R, Menendez JA. Cytokeratin 5/6 fingerprinting in HER2-positive tumors identifies a poor prognosis and trastuzumab-resistant basal-HER2 subtype of breast cancer. Oncotarget. 2015; 6:7104-7122. doi: 10.18632/oncotarget.3106. 